\title{
Burden of disease associated with a COPD eosinophilic phenotype
}

This article was published in the following Dove Press journal:

International Journal of COPD

\author{
Hector Ortega' \\ Jean-Pierre Llanos ${ }^{2}$ \\ Marie-Hélène Lafeuille ${ }^{3}$ \\ Guillaume Germain ${ }^{3}$ \\ Mei Sheng Duh ${ }^{4}$ \\ Christopher F Bell ${ }^{2}$ \\ Susan R Sama ${ }^{5}$ \\ Beth Hahn² \\ 'Respiratory, US Medical Affairs, \\ GSK, La Jolla, CA, USA; ${ }^{2}$ Respiratory, \\ US Medical Affairs, GSK Research \\ Triangle Park, NC, USA; ${ }^{3}$ Groupe \\ d'analyse, Ltée, Montréal, QC, Canada; \\ ${ }^{4}$ Analysis Group, Inc., Boston, MA, \\ USA; ${ }^{5}$ Research Department, Reliant \\ Medical Group, Worcester, MA, USA
}

Correspondence: Beth Hahn US Value Evidence \& Outcomes, GSK, 5 Moore Drive, Research Triangle Park, NC 27709-3398, USA

$\mathrm{Tel}+19192740660$

Email beth.a.hahn@gsk.com
Purpose: Based on blood and sputum samples, up to $40 \%$ of patients with COPD have eosinophilic inflammation; however, there is little epidemiology data characterizing the health care burden within this sub-population. Given that COPD-attributable medical costs in the USA are predicted to approach $\$ 50$ billion by 2020 , we analyzed the effect of blood eosinophil counts and exacerbations on health care resource utilization and costs.

Patients and methods: This cross-sectional study used electronic medical records and insurance claims data from the Reliant Medical Group (January 2011-December 2015). Eligible patients were $\geq 40$ years of age, continuously enrolled during the year of interest (2012, 2013, 2014, or 2015), had $\geq 1$ COPD-related code in the preceding year, and documented maintenance therapy use. Patients with $\geq 1$ blood eosinophil count recorded were stratified into 2 cohorts: $<150$ cells $/ \mu \mathrm{L}$ and $\geq 150$ cells $/ \mu \mathrm{L}$. Endpoints included demographics, clinical characteristics, health care resource utilization, and costs. The impact of blood eosinophil count and exacerbation patterns on health care resource utilization and costs was assessed with multivariate analyses.

Results: On average, 2,832 eligible patients were enrolled annually, of whom $\sim 28 \%$ had $\geq 1$ eosinophil count recorded during the year. The $\geq 150$ cells $/ \mu \mathrm{L}$ cohort had numerically higher all-cause and COPD-related health care resource utilization and cost each year compared with the $<150$ cells $/ \mu \mathrm{L}$ cohort, but varied by service and year. Among patients with exacerbations, the $\geq 150$ cells $/ \mu \mathrm{L}$ cohort exhibited significantly higher COPD-related costs compared with the $<150$ cells $/ \mu \mathrm{L}$ cohort.

Conclusion: Blood eosinophil counts may be a useful biomarker for burden of disease in a subgroup of patients with COPD.

Keywords: COPD triple therapy, COPD exacerbations, eosinophils, health care resource utilization

\section{Introduction}

COPD is a complex and heterogeneous condition, characterized by chronic airway inflammation, progressive airway obstruction, persistent respiratory symptoms, and acute exacerbations. ${ }^{1}$ In 2015, 3.2 million deaths were attributed to COPD, making it the fourth leading cause of death worldwide, ${ }^{2}$ and in 2016, COPD was the eighth greatest cause of disability-adjusted life years. ${ }^{3}$ In addition to this significant disease burden, COPD places an important economic burden on health care systems. COPDattributable medical costs in the USA were estimated to reach $\$ 32.1$ billion in 2010 and predicted to increase to $\$ 49.0$ billion in $2020 .^{4}$

Much of COPD morbidity and mortality is associated with severe exacerbations, ${ }^{5}$ during which airway inflammation may play a significant role. In some patients, this inflammation is predominantly neutrophilic; however, studies have reported that a 
subgroup of patients exhibit an increase in sputum eosinophil counts ( $\geq 3 \%$ ) during exacerbations. ${ }^{6}$ Additionally, in small interventional trials, up to $40 \%$ of patients with COPD exhibit an eosinophilic phenotype (based on a sputum criterion) during stable disease and exacerbations..$^{7-9}$

Although eosinophilic airway inflammation has traditionally been assessed by sputum eosinophil counts $\geq 2 \%$ or $\geq 3 \%$, there is also evidence to support the use of peripheral blood eosinophil counts as a diagnostic biomarker to define an eosinophilic COPD phenotype. Analysis of the ECLIPSE study population demonstrated that $37 \%$ of patients with COPD persistently presented with blood eosinophil counts $\geq 2 \% .{ }^{10}$ Furthermore, assessments of the relationship between induced sputum and peripheral blood eosinophil counts have demonstrated a significant association between increased eosinophil levels in the sputum, blood, and lungs; ${ }^{11}$ and cluster analyses have shown that peripheral blood eosinophil counts $>2 \%$ can predict sputum eosinophilia during exacerbations with a $60 \%$ specificity and $90 \%$ sensitivity. ${ }^{12}$

An eosinophilic phenotype based on a blood eosinophil count $\geq 2 \%$, or the highly correlated value of $\geq 150$ cells $/ \mu \mathrm{L},{ }^{10}$ has been associated with increased COPD exacerbations, ${ }^{13}$ and better response to eosinophil-targeting treatments in patients with COPD and asthma. ${ }^{13-15}$ However, there is still uncertainty on how health care resource utilization and costs vary across the continuum of eosinophilic and noneosinophilic phenotypes, and within this COPD eosinophilic phenotype.

The objective of this study was to use real-world epidemiology data to characterize a COPD population per demographic and clinical characteristics. Based on the association between blood eosinophil counts $\geq 150$ cells $/ \mu \mathrm{L}$ and increased COPD exacerbations, we evaluated the impact of blood eosinophil counts $<150$ cells $/ \mu \mathrm{L}$ and $\geq 150$ cells $/ \mu \mathrm{L}$ on health care resource utilization and costs among patients with and without exacerbations, and also the presence of exacerbations among patients with blood eosinophil counts $<150$ cells $/ \mu \mathrm{L}$ or $\geq 150$ cells $/ \mu \mathrm{L}$.

\section{Materials and methods \\ Study design and data source}

This cross-sectional study was conducted using electronic medical record (EMR) and claims data from January 1, 2011 to December 31, 2015. Patients were observed on an annual basis for years 2012, 2013, 2014, and 2015. EMR and insurance claims data were sourced from the Reliant Medical Group, a large, multi-specialty group practice in central Massachusetts (see Supplementary Materials for details).

\section{Study participants}

Eligible patients were $\geq 40$ years of age, had continuous clinical activity throughout the calendar year of interest (except for 2015, where patients had to be clinically active for at least the first 9 months of the year), with $\geq 1$ COPD-related code in the preceding year (Supplementary Materials), and $\geq 1$ prescription for inhaled maintenance therapy (MT), involving either an inhaled corticosteroid (ICS), long-acting $\beta_{2}$-agonist (LABA), long-acting muscarinic antagonists (LAMA) or a combination, during the calendar year of interest.

\section{Cohorts for analysis}

All patients who met the inclusion criteria for the calendar year of interest were included in the MT population. EMR and claims data were used to define subgroups: 1) patients with $\geq 1$ blood eosinophil count during the calendar year of interest; 2) patients with triple therapy use (defined as a prescription for either 3 individual inhalers [ICS + LABA + LAMA] or any 2-plus- 1 combination type for $\geq 30$ consecutive days during the calendar year of interest); and, 3) patients with moderate/severe exacerbation(s) during the calendar year of interest. COPD exacerbations were identified using a claims-based algorithm (Supplementary Materials).

Patients with $\geq 1$ blood eosinophil count recorded during the year were divided into 2 cohorts: patients with all eosinophil counts $<150$ cells $/ \mu \mathrm{L}$ (MT $<150$ cohort), and patients with $\geq 1$ eosinophil count $\geq 150$ cells $/ \mu \mathrm{L}$ (MT $\geq 150$ cohort). Patients included in $>1$ subgroup defined previously were classified in the overlapping subgroups.

\section{Outcomes}

All demographic and clinical characteristics were evaluated at the closest value on July 1, except for comorbidities, eosinophil counts, and Quan-Charlson comorbidity index (CCI) score, which were evaluated over the entire calendar year. Health care resource utilization and costs were also evaluated over the entire calendar year.

Eosinophil count-related outcomes included the proportion of patients with a blood eosinophil count recorded, the frequency of eosinophil counts per year, and the proportion of patients with a blood eosinophil count $\geq 150$, $\geq 300$, or $\geq 400$ cells $/ \mu \mathrm{L}$. For the eosinophil count classification, the highest value recorded during the calendar year of interest was used.

All-cause and COPD-related health care resource utilization outcomes were defined as the number of hospitalizations, and emergency room (ER), outpatient, and other visits during the calendar year. All-cause and COPD-related health care 
cost outcomes were total medical health care, hospitalization, and ER, outpatient, and other visit costs. COPD-related health care resource utilization and costs were identified as any claim with a relevant COPD International Classification of Disease 9 code.

\section{Statistical analysis}

Descriptive statistics were used to summarize demographics, clinical characteristics, blood eosinophil counts, and health care resource utilization and costs. Descriptive statistics included mean, SD, and median for continuous data and relative frequencies for categorical data. Cost data were standardized and reported as 2016 US dollars using the Medical Care Consumer Price Index. Statistical comparisons between groups of interest used Chi-squared tests for categorical variables, and Student $t$-tests for continuous variables. Analyses were conducted for calendar years 2012, 2013, 2014, and 2015, separately.

Multivariate analyses used generalized estimating equation models with a normal distribution, combining data across all calendar years of interest (2012-2015), and controlling for repeated patients using an unstructured correlation matrix. Models were used to calculate the unadjusted and adjusted total medical health care cost difference between: 1) patients with blood eosinophil counts $<150$ cells $/ \mu \mathrm{L}$ and $\geq 150$ cells $/ \mu \mathrm{L}$ in patients with and without exacerbations and, 2) patients with and without exacerbations in the $\mathrm{MT}<150$ and MT $\geq 150$ cohorts. Multivariate analyses were also repeated using a threshold of 300 cells $/ \mu \mathrm{L}$. In both cases adjustments were made for: age, gender, insurance type, body mass index, blood pressure, calendar year, asthma, malignant neoplasm of respiratory and intrathoracic system, rheumatoid arthritis, Crohn's disease, systemic lupus erythematosus, multiple sclerosis, allergic rhinitis, respiratory infections, chronic sinusitis, diabetes, cardiovascular disease, acute sinusitis, atopic dermatitis, eosinophilic granulomatosis with polyangiitis, nasal polyps, hypereosinophilic syndrome, eosinophilic esophagitis, bacterial infections, CCI score, and triple therapy use.

Due to the large number of covariates, a sensitivity analysis adjusting for fewer characteristics was also conducted (Supplementary Materials). All analyses were conducted using SAS, version 9.3 or later (SAS Institute, Cary, NC, USA). This research was a retrospective analysis of de-identified administrative claims data and as such did not require approval from an ethics committee or institutional review board. However, approval was obtained from the Reliant Medical Group's institutional review board. The data used in this analysis are not publicly available as these are de-identified claims data.

\section{Results \\ Study population and clinical characteristics}

In total, 11,895 unique patients with a diagnosis of COPD during the preceding year were identified for the calendar years 2012-2015. A total of 2,802, 2,822, 2,847, and 2,858 patients were eligible for the MT population in 2012, 2013, 2014, and 2015 , respectively. There was consistency across years regarding most demographic factors. Patients identified were on average 70 years of age and $\sim 60 \%$ were female (Table 1 ).

In any given year, just over a quarter $(\sim 28 \%)$ of the patients in the MT population had a blood eosinophil count recorded. Of those, $\sim 72 \%$ had $\geq 1$ blood eosinophil count $\geq 150$ cells/ $\mu \mathrm{L}$. The percentage of MT patients with $\geq 1$ exacerbation within a year ranged from $16 \%$ (2014) to $28 \%$ (2012), whereas the percentage of patients with triple therapy was relatively constant across the years $(\sim 20 \%)$. Overall, the proportion of patients in the MT $\geq 150$ cohort with a history of exacerbation or triple therapy use was comparable with that of the MT population. The proportion of patients in the overlapping subgroups varied across the years examined (Figure 1).

\section{Health care resource utilization and cost by blood eosinophil count}

Patients in MT $\geq 150$ cohort had unadjusted numerically higher COPD-related health care resource utilization each year compared with patients in the MT $<150$ cohort; however, statistically significant differences varied by service and year (Figure 2). In 2012, COPD-related health care resource utilization, in terms of hospitalization, outpatient, and other visits, was significantly higher among the MT $\geq 150$ cohort, compared with the MT <150 cohort; however, in 2013, only COPD-related ER visits were significantly higher in the $\mathrm{MT} \geq 150$ cohort. All-cause health care resource utilization, in terms of hospitalizations, outpatient visits, and other visits, was significantly higher in the $\mathrm{MT} \geq 150$ cohort than the MT <150 cohort in 2012 and 2014; however, only allcause ER visits in 2013, and all-cause outpatient visits in 2015 , were significantly higher in the MT $\geq 150$ cohort vs the MT < 150 cohort (Table 2).

All-cause and COPD-related health care costs were also numerically higher for the MT $\geq 150$ cohort in each year of interest, as compared with the MT $<150$ cohort. Statistically significant differences varied by service and year, except all-cause total health care cost, which was significantly 
Table I Demographic characteristics and comorbidities in the MT population, 20I2-20I5

\begin{tabular}{|c|c|c|c|c|}
\hline \multirow[t]{3}{*}{ MT population } & \multicolumn{4}{|l|}{ Year } \\
\hline & \multirow{2}{*}{$\frac{2012}{N=2,802}$} & \multirow{2}{*}{$\frac{2013}{N=2,822}$} & \multirow{2}{*}{$\frac{2014}{N=2,847}$} & \multirow{2}{*}{$\frac{2015}{N=2,858}$} \\
\hline & & & & \\
\hline Age at index date (years), ${ }^{a}$ mean \pm SD & $70.0 \pm 11.8$ & $69.9 \pm 11.7$ & $70.1 \pm I I .5$ & $70.3 \pm 11.4$ \\
\hline Male, ${ }^{\mathrm{a}} \mathrm{n}(\%)$ & $\mathrm{I}, 184(42.3)$ & $\mathrm{I}, 202(42.6)$ & $\mathrm{I}, 222(42.9)$ & $1,204(42.1)$ \\
\hline \multicolumn{5}{|l|}{ Insurance type, ${ }^{\mathrm{a}} \mathrm{n}(\%)$} \\
\hline Commercial & $252(9.0)$ & $255(9.0)$ & $304(10.7)$ & $305(10.7)$ \\
\hline Medicare & $\mathrm{I}, 173(41.9)$ & $\mathrm{I}, \mathrm{I} 64(4 \mathrm{I} .2)$ & $\mathrm{I}, 090(38.3)$ & $\mathrm{I}, 167(40.8)$ \\
\hline Medicaid & $74(2.6)$ & $67(2.4)$ & $45(1.6)$ & $117(4.1)$ \\
\hline Unknown & I,303 (46.5) & I,336 (47.3) & $\mathrm{I}, 408(49.5)$ & $1,269(44.4)$ \\
\hline \multicolumn{5}{|l|}{ Body mass index ${ }^{a}$} \\
\hline Number of patients, n (\%) & $2,653(94.7)$ & $2,65 I(93.9)$ & $2,661(93.5)$ & $2,748(96.2)$ \\
\hline Mean \pm SD (median) & $29.3 \pm 7.4(28)$ & $29.4 \pm 7.4(28)$ & $29.3 \pm 7.4(28)$ & $29.2 \pm 7.4(28)$ \\
\hline Quan-Charlson comorbidity index, ${ }^{\mathrm{b}}$ mean $\pm \mathrm{SD}$ & $2.5 \pm 2.9$ & $2.4 \pm 3.0$ & $2.1 \pm 2.9$ & $2.9 \pm 3.0$ \\
\hline \multicolumn{5}{|l|}{ Comorbidities, ${ }^{\text {b }}$ (\%) } \\
\hline Cardiovascular disease & $2,114(75.4)$ & $2,142(75.9)$ & $2,120(74.5)$ & $2,239(78.3)$ \\
\hline Diabetes & $891(31.8)$ & $873(30.9)$ & $812(28.5)$ & $843(29.5)$ \\
\hline Asthma & $690(24.6)$ & $667(23.6)$ & $635(22.3)$ & $583(20.4)$ \\
\hline Respiratory infections & $503(18.0)$ & $478(16.9)$ & $470(16.5)$ & $517(18.1)$ \\
\hline Allergic rhinitis & $316(11.3)$ & $323(11.4)$ & $343(12.0)$ & $345(12.1)$ \\
\hline Chronic sinusitis & $197(7.0)$ & $|8|(6.4)$ & $209(7.3)$ & $176(6.2)$ \\
\hline Acute sinusitis & $120(4.3)$ & $77(2.7)$ & $82(2.9)$ & $129(4.5)$ \\
\hline Rheumatoid arthritis & $52(1.9)$ & $56(2.0)$ & $53(1.9)$ & $64(2.2)$ \\
\hline \multicolumn{5}{|l|}{ Blood eosinophil measure ${ }^{c}$} \\
\hline Number of patients, n (\%) & $773(27.6)$ & $768(27.2)$ & $788(27.7)$ & $803(28.1)$ \\
\hline Number of measures, mean $\pm S D$ (median) & $4.3 \pm 5.6(2)$ & $4.6 \pm 6.4(2)$ & $4.5 \pm 6.1(2)$ & $4.7 \pm 6.6(2)$ \\
\hline Eosinophil cells $/ \mu \mathrm{L}$, mean $\pm \mathrm{SD}$ (median) & $288.9 \pm 268.0(226)$ & $289.3 \pm 243.9(221)$ & $309.2 \pm 284.4(231)$ & $302.7 \pm 259.2(238)$ \\
\hline$\geq 150$ cells $/ \mu \mathrm{L}, \mathrm{n}(\%)$ & $548(70.9)$ & $562(73.2)$ & $575(73.0)$ & $592(73.7)$ \\
\hline$\geq 300$ cells/ $\mu \mathrm{L}, \mathrm{n}(\%)$ & $298(38.6)$ & $282(36.7)$ & $326(4 I .4)$ & $321(40.0)$ \\
\hline$\geq 400$ cells/ $\mu \mathrm{L}, \mathrm{n}(\%)$ & $184(23.8)$ & $189(24.6)$ & $203(25.8)$ & $196(24.4)$ \\
\hline
\end{tabular}

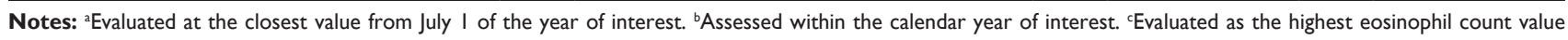
during the calendar year of interest.

Abbreviation: MT, maintenance therapy.

higher in the MT $\geq 150$ cohort than the MT $<150$ cohort across all 4 years (Table S1). Notably, hospitalization was the biggest driver of cost difference between the MT $<150$ and MT $\geq 150$ cohorts, with COPD-related and all-cause hospitalization costs being significantly higher in the MT $\geq 150$ cohort than the MT <150 cohort in 2012 and 2013.

\section{Interaction of blood eosinophil count and COPD exacerbations on health \\ care costs}

The multivariate analysis showed that, among patients with exacerbations, those in the MT $\geq 150$ cohort had significantly higher COPD-related health care costs (adjusted cost difference: $\$ 9,800, P=0.006$ ) and all-cause health care costs (adjusted cost difference: $\$ 14,412, P=0.002$ ), compared with those in the MT $<150$ cohort. For patients without exacerbations, there was a non-significant trend toward higher all-cause health care costs for the MT $\geq 150$ cohort compared with MT $<150$ cohort (adjusted cost difference: $\$ 218, P=0.915$; Figure 3).
Multivariate analyses also showed significantly higher COPD-related and all-cause health care costs for patients with exacerbations vs those without exacerbations in both the MT $<150$ cohort (adjusted cost differences: $\$ 16,114$, $P<0.0001 ; \$ 14,413, P=0.0003$, respectively) and the MT $\geq 150$ cohorts (adjusted cost differences: $\$ 26,314$, $P<0.0001 ; \$ 28,607, P<0.0001$, respectively; Figure 4). The sensitivity analysis adjusting for fewer covariates produced comparable results (Figures S1 and $\underline{\mathrm{S} 2}$ ).

Multivariate analyses using the 300 cells $/ \mu \mathrm{L}$ threshold also had similar trend and significance to those using the lower threshold of 150 cells $/ \mu \mathrm{L}$ (Figures S3 and $\underline{\mathrm{S}}$ ).

\section{Discussion}

The results of this study suggest that health care resource utilization and cost differ with blood eosinophil counts in a subgroup of patients with COPD. Regardless of eosinophil counts, exacerbations were associated with significantly higher all-cause and COPD-related health care costs. 

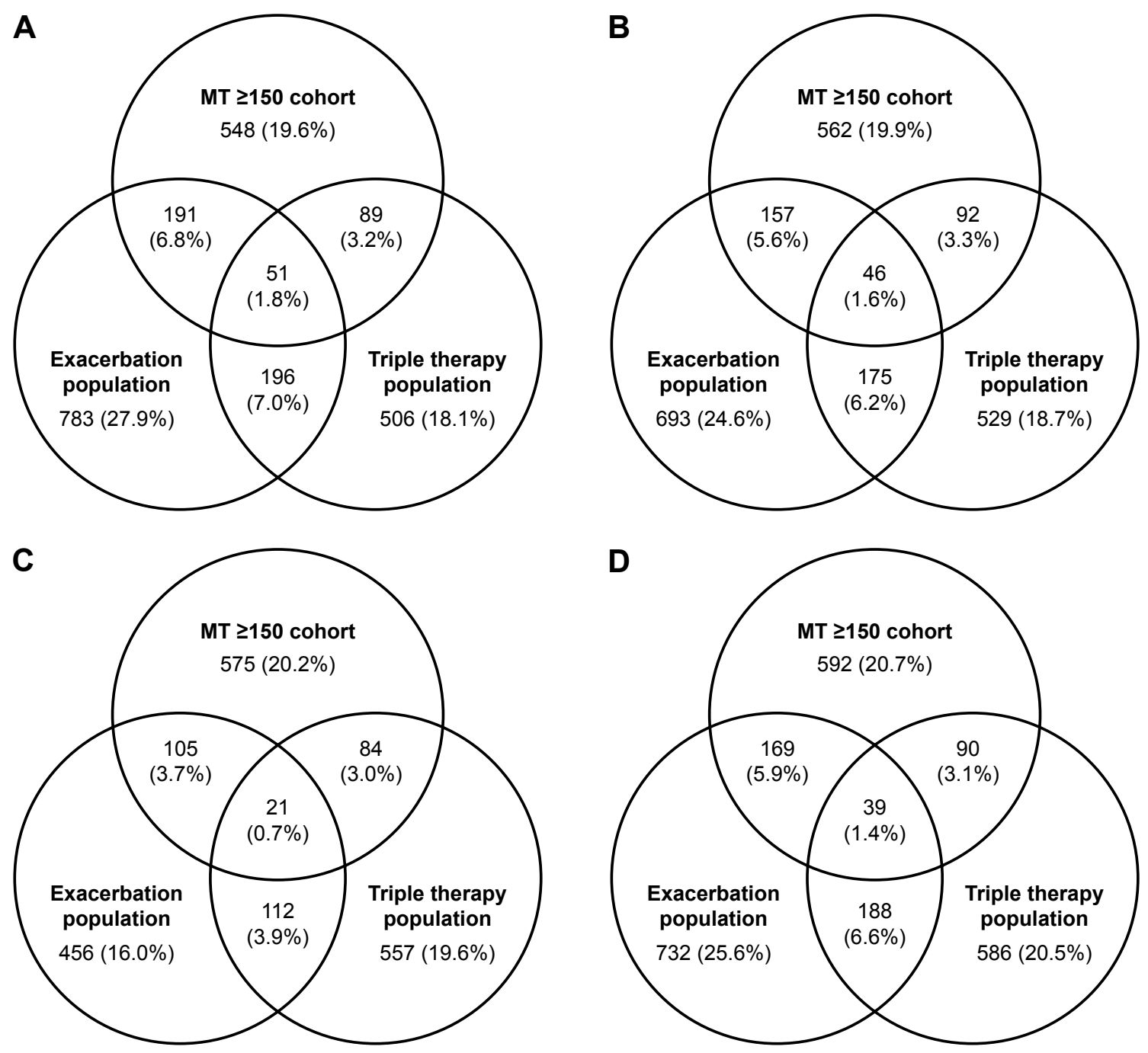

Figure I Proportions of patients in subgroups of clinical interest* for the calendar years 2012 (A), 2013 (B), 2014 (C), and 2015 (D).

Notes: (A) 2012; MT population $\mathrm{N}=2,802$. (B) 2013; MT population $\mathrm{N}=2$ 2,822. (C) 2014; MT population $\mathrm{N}=2,847$. (D) 2015; MT population $\mathrm{N}=2,858$. *Discrepancies between the sum of patients in the 3 subgroups of clinical interest and the MT population each year are accounted for by patients in the MT population who did not meet the criteria for any subgroup of clinical interest.

Abbreviation: MT, maintenance therapy.

However, among patients with exacerbations, eosinophil counts $\geq 150$ cells $/ \mu \mathrm{L}$ were associated with significantly higher all-cause and COPD-related health care costs than eosinophil counts $<150$ cells $/ \mu \mathrm{L}$. In our models, the adjusted cost differences for COPD-related and all-cause medical health care costs between eosinophil count cohorts were around $\$ 10,000$ per year, highlighting a substantial burden on the health care system. Together, these results suggest that higher peripheral blood eosinophil levels represent an additional burden to patients with COPD and exacerbations, and this sub-population requires significantly greater health care resource utilization and associated costs.

Numerous epidemiological studies have demonstrated associations between peripheral blood eosinophil counts and important clinical outcomes in COPD. ${ }^{16}$ A study in the Netherlands found COPD-specific mortality to be increased in patients with a peripheral blood eosinophil count $\geq 275$ cells/ $\mu \mathrm{L} .{ }^{17}$ Epidemiological analyses of the Copenhagen General Population Study reported blood eosinophil counts $\geq 340$ cells $/ \mu \mathrm{L}$ to be associated with increased risk of severe exacerbations. ${ }^{6}$ Additionally, a recent randomized controlled trial reported lower rates of COPD exacerbations in patients with blood eosinophil counts $<150$ cells $/ \mu \mathrm{L}$ vs $\geq 150$ cells/ $\mu \mathrm{L} .{ }^{13}$ In contrast, analysis of the ECLIPSE study did not find an association between blood eosinophil count and COPD exacerbations. ${ }^{10}$

Several studies have also suggested that peripheral blood eosinophil counts may predict patient response to ICS therapy. ${ }^{18-20}$ 
2012

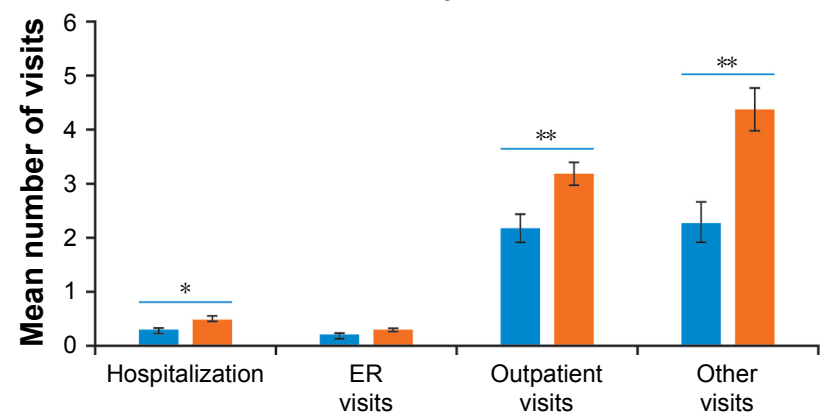

Health care resource utilization

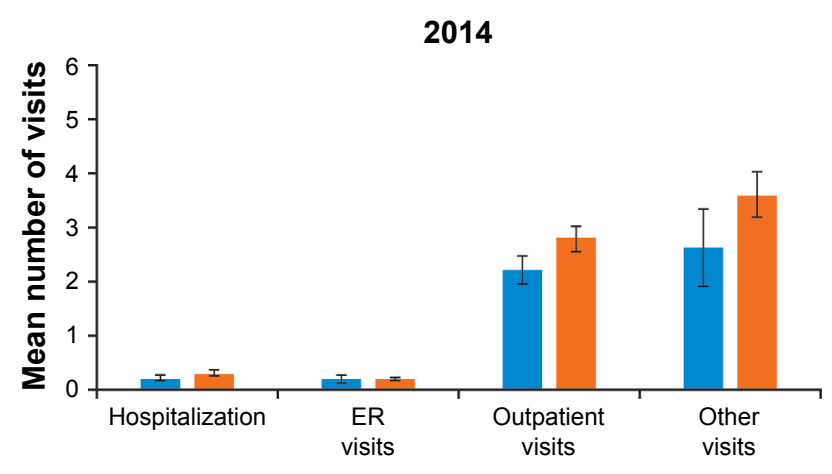

Health care resource utilization

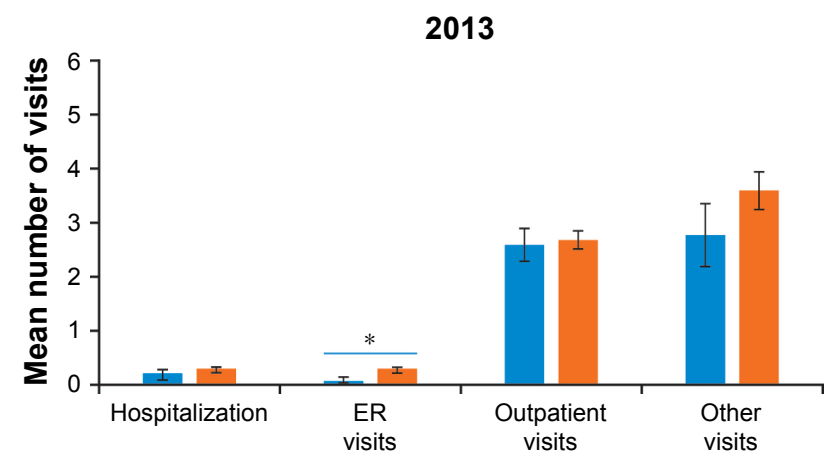

Health care resource utilization

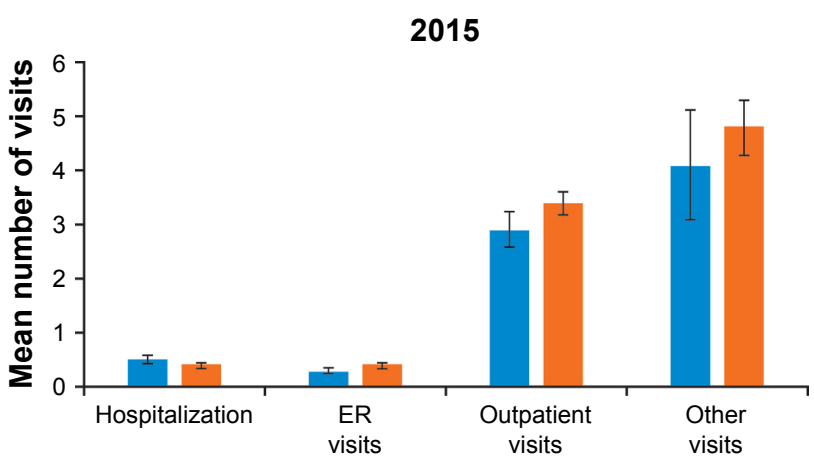

Health care resource utilization

Blood eosinophil count $<150$ cells $/ \mu \mathrm{L} \quad$ Blood eosinophil count $\geq 150$ cells $/ \mu \mathrm{L}$

Figure 2 COPD-related health care resource utilization by blood eosinophil count cohort for years 20I2-20I5.

Notes: Statistically significant differences between cohorts are indicated as $* P \leq 0.01, * * P \leq 0.001$. Error bars show standard error.

Abbreviation: ER, emergency room.

A retrospective analysis of 3 randomized controlled trials demonstrated that in patients with baseline blood eosinophil counts $\geq 2 \%$, exacerbation rates were significantly reduced in response to ICS/LABA therapy compared with anticholinergic bronchodilator or placebo. No significant difference was observed between treatment options in patients with blood eosinophil counts $<2 \%$. ${ }^{18}$ Similarly, Pascoe et al demonstrated that in patients with blood eosinophil counts $\geq 2 \%$, but not $<2 \%$, annualized exacerbation rates were significantly reduced in response to ICS/LABA therapy vs LABA alone. ${ }^{20}$
Results of this present study suggest that in addition to their potential as a biomarker associated with exacerbations and therapy response, peripheral blood eosinophil counts could serve as a biomarker for identifying patients with COPD who experience a higher burden of disease. Prospective studies are needed to further clarify the role of blood eosinophil counts as a biomarker in COPD, as different thresholds may be required for predicting clinical outcomes and burden of disease. Our results demonstrate that a threshold of 150 cells $/ \mu \mathrm{L}$ is sensitive enough to distinguish patients with greater health

Table 2 Annual all-cause health care resource utilization by blood eosinophil count cohort (20I2-20I5)

\begin{tabular}{|c|c|c|c|c|c|c|c|c|}
\hline \multirow{2}{*}{$\begin{array}{l}\text { All-cause health } \\
\text { care resource } \\
\text { utilization, } \\
\text { mean } \pm S D\end{array}$} & \multicolumn{2}{|c|}{$\begin{array}{l}20 I 2 \text { patients with blood } \\
\text { eosinophil count }(N=773)\end{array}$} & \multicolumn{2}{|c|}{$\begin{array}{l}20 I 3 \text { patients with blood } \\
\text { eosinophil count }(N=768)\end{array}$} & \multicolumn{2}{|c|}{$\begin{array}{l}20 \text { I } 4 \text { patients with blood } \\
\text { eosinophil count }(N=788)\end{array}$} & \multicolumn{2}{|c|}{$\begin{array}{l}20 \text { I } 5 \text { patients with blood } \\
\text { eosinophil count }(N=803)\end{array}$} \\
\hline & $\begin{array}{l}\text { Eosinophil } \\
\text { count }<\text { I50 } \\
\text { cells/ } \mu \mathrm{L} \\
(\mathrm{n}=225)\end{array}$ & $\begin{array}{l}\text { Eosinophil } \\
\text { count } \geq 150 \\
\text { cells/ } \mu L \\
(n=548)\end{array}$ & $\begin{array}{l}\text { Eosinophil } \\
\text { count }<150 \\
\text { cells/ } \mu \mathrm{L} \\
(\mathrm{n}=206)\end{array}$ & $\begin{array}{l}\text { Eosinophil } \\
\text { count } \geq 150 \\
\text { cells } / \mu L \\
(n=562)\end{array}$ & $\begin{array}{l}\text { Eosinophil } \\
\text { count }<150 \\
\text { cells } / \mu L \\
(n=213)\end{array}$ & $\begin{array}{l}\text { Eosinophil } \\
\text { count } \geq 150 \\
\text { cells } / \mu L \\
(n=575)\end{array}$ & $\begin{array}{l}\text { Eosinophil } \\
\text { count }<150 \\
\text { cells/ } \mu \mathrm{L} \\
(\mathrm{n}=2 \mathrm{II})\end{array}$ & $\begin{array}{l}\text { Eosinophil } \\
\text { count } \geq I 50 \\
\text { cells/ } \mu \mathrm{L} \\
(\mathrm{n}=\mathbf{5 9 2})\end{array}$ \\
\hline Hospitalizations & $0.5 \pm 1.2^{\mathrm{a}}$ & $0.8 \pm 1.7^{\mathrm{a}}$ & $0.4 \pm 1.5$ & $0.6 \pm 1.3$ & $0.3 \pm 1.0^{\mathrm{a}}$ & $0.4 \pm 1 . I^{a}$ & $0.6 \pm 1.6$ & $0.6 \pm 1.3$ \\
\hline ER visits & $0.5 \pm 1.3$ & $0.6 \pm 1.2$ & $0.4 \pm 1.5^{\mathrm{a}}$ & $0.7 \pm 2.0^{\mathrm{a}}$ & $0.4 \pm 1.2$ & $0.5 \pm 1.2$ & $0.8 \pm 1.7$ & $1.0 \pm 3.0$ \\
\hline Outpatient visits & $16.9 \pm 16.9^{a}$ & $20.1 \pm 17.2^{\mathrm{a}}$ & $17.5 \pm 17.8$ & $18.3 \pm 17.9$ & $12.7 \pm 15.0^{\mathrm{a}}$ & $15.6 \pm 18.0^{\mathrm{a}}$ & $16.0 \pm 14.5^{b}$ & $20.1 \pm 18.5^{b}$ \\
\hline Other visits & $1|.7 \pm 15 .|^{c}$ & $17.9 \pm 23.3^{c}$ & $15.1 \pm 24.2$ & $18.5 \pm 30.2$ & $9.1 \pm 16.2^{\mathrm{a}}$ & $12.0 \pm 19.7^{a}$ & $14.0 \pm 23.9$ & $15.7 \pm 20.8$ \\
\hline
\end{tabular}

Note: Statistical significance is indicated as ${ }^{a} P \leq 0.05,{ }^{b} P \leq 0.0 \mathrm{I},{ }^{c} P \leq 0.00 \mathrm{I}$.

Abbreviation: ER, emergency room. 
A

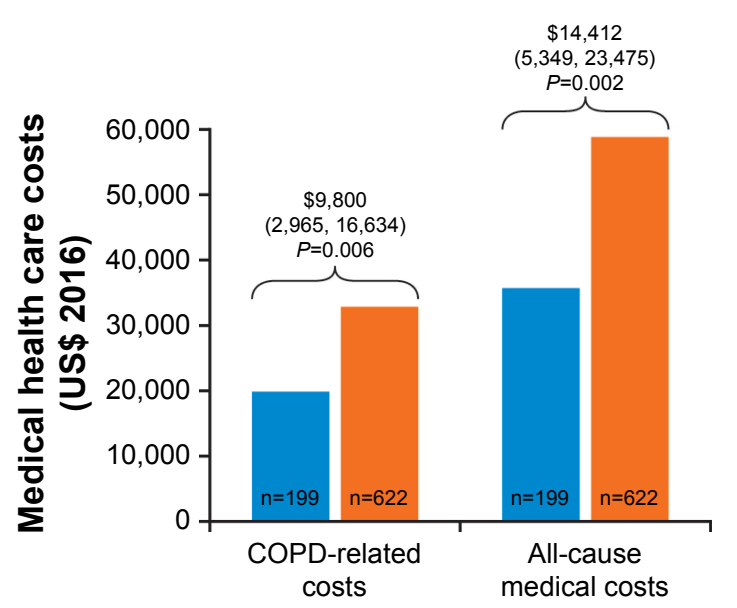

Blood eosinophil count $<150$ cells $/ \mu \mathrm{L}$

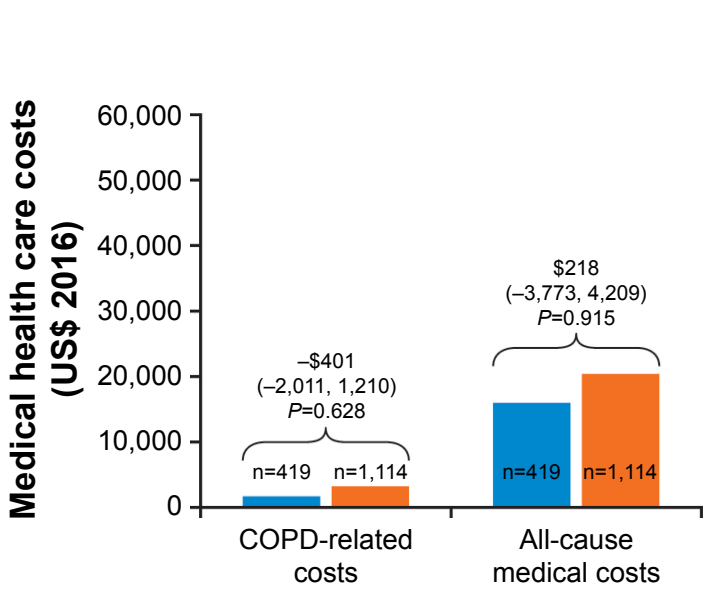

Patients without exacerbations

Blood eosinophil count $\geq 150$ cells/ $\mu \mathrm{L}$

Figure 3 Multivariate analysis of COPD-related and all-cause annual medical costs for patients with blood eosinophil counts $<150$ cells $/ \mu \mathrm{L}$ and $\geq 150$ cells/ $\mu \mathrm{L}$, either with exacerbations (A) or without exacerbations (B).

Notes: Numbers show adjusted* cost differences, $95 \% \mathrm{Cls}$, and adjusted $\mathrm{P}$-values. *Adjusting for age, gender, insurance type, BMI, blood pressure, calendar year, asthma, malignant neoplasm of respiratory and intrathoracic system, rheumatoid arthritis, Crohn's disease, systemic lupus erythematosus, multiple sclerosis, allergic rhinitis, respiratory infections, chronic sinusitis, diabetes, cardiovascular disease, acute sinusitis, atopic dermatitis, eosinophilic granulomatosis with polyangiitis, nasal polyps, hypereosinophilic syndrome, eosinophilic esophagitis, bacterial infections, $\mathrm{CCl}$ score, and triple therapy use.

Abbreviations: BMI, body mass index; $\mathrm{CCl}$, Quan-Charlson comorbidity index.

care resource utilization and associated costs. However, it should be noted that while this threshold may indicate an eosinophilic COPD phenotype, it does not necessarily represent eosinophilia.
This study had several limitations. Only one quarter of patients included in the study population had a blood eosinophil count recorded; hence, the absence of a blood eosinophil count $\geq 150$ cells $/ \mu \mathrm{L}$ does not necessarily indicate that a

\section{A \\ Blood eosinophil count $<150$ cells $/ \mu \mathrm{L}$}

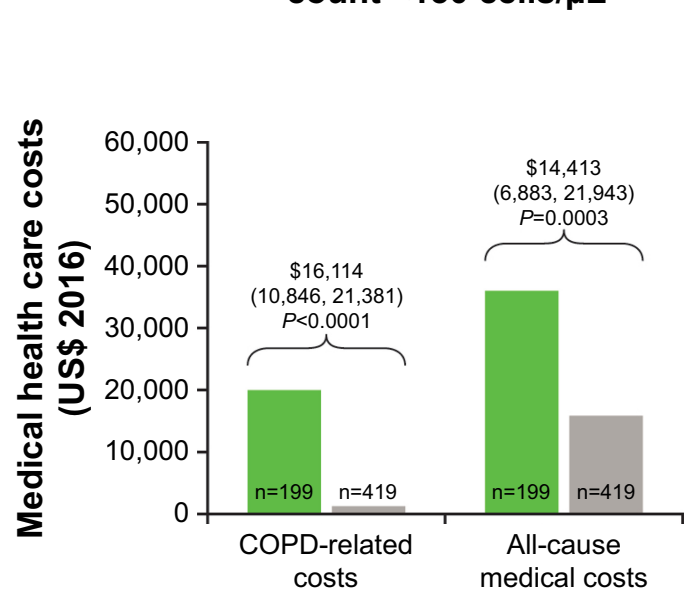

B

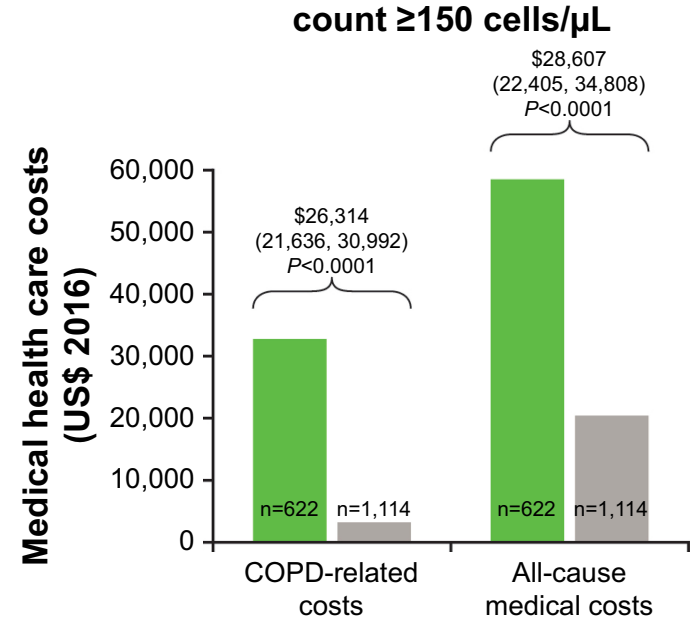

With exacerbations Without exacerbations

Figure 4 Multivariate analysis of COPD-related and all-cause annual medical costs for patients with and without exacerbations, with either blood eosinophil count $<150$ cells $/ \mu \mathrm{L}(\mathbf{A})$ or $\geq 150$ cells $/ \mu \mathrm{L}$ (B).

Notes: Numbers show adjusted* cost differences, $95 \% \mathrm{Cls}$, and adjusted $P$-values. *Adjusting for age, gender, insurance type, BMI, blood pressure, calendar year, asthma, malignant neoplasm of respiratory and intrathoracic system, rheumatoid arthritis, Crohn's disease, systemic lupus erythematosus, multiple sclerosis, allergic rhinitis, respiratory infections, chronic sinusitis, diabetes, cardiovascular disease, acute sinusitis, atopic dermatitis, eosinophilic granulomatosis with polyangiitis, nasal polyps, hypereosinophilic syndrome, eosinophilic esophagitis, bacterial infections, $\mathrm{CCl}$ score, and triple therapy use.

Abbreviations: BMI, body mass index; $\mathrm{CCl}$, Quan-Charlson comorbidity index. 
patient was not of an eosinophilic phenotype, only that their blood eosinophil level was not measured. Additionally, it is unknown when blood eosinophil counts were taken relative to health status (ie, during normal health or sickness); testing may have only been performed in a sub-population of patients exhibiting more severe disease. As such, patients with an eosinophil count recorded may not be representative of the MT population, and results of the analysis of blood eosinophil count on outcomes might not reflect the overall COPD population. It was not possible to directly assess COPD severity based on lung function because spirometry results were not available. Instead, adjustment for COPD severity was limited to treatments received, COPD exacerbations, specific comorbidities, and health care resource utilization and costs. Additionally, identification of exacerbations was based on a claims-based algorithm, therefore, it was not possible to confirm COPD exacerbations, nor check that all COPD exacerbations were captured. The exacerbation population in 2014 was smaller than in other years due to differences in data collection during that year. In particular, some provider claims were not supplied making it likely that exacerbations were underreported in the population of patients assessed during 2014. Finally, the database used for this study only included patients from Massachusetts, so the results may not be generalizable to the whole of the USA. Furthermore, $20 \%-25 \%$ of patients in the MT population each year were also diagnosed with asthma, which may have confounded the results of this study.

\section{Conclusion}

This study demonstrates an impact of blood eosinophil counts $\geq 150$ cells $/ \mu \mathrm{L}$ in patients with COPD and exacerbations. Among patients with a history of exacerbations, those with at least 1 blood eosinophil count $\geq 150$ cells $/ \mu \mathrm{L}$ had significantly higher all-cause and COPD-related health care costs, compared with patients with all blood eosinophil counts $<150$ cells $/ \mu \mathrm{L}$, indicating that blood eosinophil counts may be a helpful biomarker associated to burden of disease in a subset of patients with COPD.

\section{Acknowledgments}

Editorial support (in the form of writing assistance, including development of the initial draft, assembling tables and figures, collating authors' comments, grammatical editing, and referencing) was provided by Natasha Dean and Susan Parker from Fishawack Indicia Ltd, UK, and was funded by GlaxoSmithKline (GSK). This study was funded by GSK (ID HO-16-16496). All authors had roles in the conception, design, and interpretation of the analysis. All authors participated in the development of the manuscript and had access to the data from the study. The decision to submit for publication was that of the authors alone. The sponsor did not place any restrictions on access to the data or the statements made in the manuscript. The corresponding author had final responsibility for the decision to submit for publication.

\section{Author contributions}

$\mathrm{BH}, \mathrm{HO}, \mathrm{CFB}, \mathrm{J}-\mathrm{PL}, \mathrm{MSD}, \mathrm{GG}$, and M-HL were involved in the conception and design of the study. MSD, GG, M-HL, and SRS were involved in data acquisition. $\mathrm{BH}, \mathrm{HO}, \mathrm{CFB}$, J-PL, GG, and M-HL were involved in data analysis or interpretation. All authors contributed toward data analysis, drafting and revising the paper and agree to be accountable for all aspects of the work.

\section{Disclosure}

HO, J-PL, CFB, and BH are GSK employees and hold stocks/ shares. M-HL, MSD, and GG are employees of Analysis Group, Inc., a consulting company that has received research funds from GSK. SRS is an employee of Reliant Medical Group (RMG) Research Department, which has received research funds from GSK. The authors report no other conflicts of interest in this work.

\section{References}

1. Vestbo J, Hurd SS, Agustí AG, et al. Global strategy for the diagnosis, management, and prevention of chronic obstructive pulmonary disease: GOLD executive summary. Am J Respir Crit Care Med. 2013;187(4): 347-365.

2. The top 10 causes of death; 2017. Available from: http://www.who.int/ mediacentre/factsheets/fs310/en/. Accessed October 16, 2017.

3. GBD 2016 DALYs and HALE Collaborators. Global, regional, and national disability-adjusted life-years (DALYs) for 333 diseases and injuries and healthy life expectancy (HALE) for 195 countries and territories, 1990-2016: a systematic analysis for the Global Burden of Disease Study 2016. Lancet. 2017;390(10100):1260-1344.

4. Ford ES, Murphy LB, Khavjou O, Giles WH, Holt JB, Croft JB. Total and state-specific medical and absenteeism costs of COPD among adults aged $\geq 18$ years in the United States for 2010 and projections through 2020. Chest. 2015;147(1):31-45.

5. Seemungal TA, Donaldson GC, Paul EA, Bestall JC, Jeffries DJ, Wedzicha JA. Effect of exacerbation on quality of life in patients with chronic obstructive pulmonary disease. Am J Respir Crit Care Med. 1998;157(5 Pt 1):1418-1422.

6. Vedel-Krogh S, Nielsen SF, Lange P, Vestbo J, Nordestgaard BG. Blood Eosinophils and Exacerbations in Chronic Obstructive Pulmonary Disease. The Copenhagen General Population Study. Am J Respir Crit Care Med. 2016;193(9):965-974.

7. Brightling CE, Monteiro W, Ward R, et al. Sputum eosinophilia and shortterm response to prednisolone in chronic obstructive pulmonary disease: a randomised controlled trial. Lancet. 2000;356(9240):1480-1485.

8. Leigh R, Pizzichini MM, Morris MM, Maltais F, Hargreave FE, Pizzichini E. Stable COPD: predicting benefit from high-dose inhaled corticosteroid treatment. Eur Respir J. 2006;27(5):964-971. 
9. Siva R, Green RH, Brightling CE, et al. Eosinophilic airway inflammation and exacerbations of COPD: a randomised controlled trial. Eur Respir J. 2007;29(5):906-913.

10. Singh D, Kolsum U, Brightling CE, et al. Eosinophilic inflammation in COPD: prevalence and clinical characteristics. Eur Respir J. 2014; 44(6):1697-1700.

11. Kolsum U, Damera G, Pham TH, et al. Pulmonary inflammation in patients with chronic obstructive pulmonary disease with higher blood eosinophil counts. J Allergy Clin Immunol. 2017;140(4):1181-1184e7.

12. Bafadhel M, Mckenna S, Terry S, et al. Acute exacerbations of chronic obstructive pulmonary disease: identification of biologic clusters and their biomarkers. Am J Respir Crit Care Med. 2011;184(6):662-671.

13. Pavord ID, Chanez P, Criner GJ, et al. Mepolizumab for Eosinophilic Chronic Obstructive Pulmonary Disease. N Engl J Med. 2017;377(17): 1613-1629.

14. Ortega HG, Yancey SW, Mayer B, et al. Severe eosinophilic asthma treated with mepolizumab stratified by baseline eosinophil thresholds: a secondary analysis of the DREAM and MENSA studies. Lancet Respir Med. 2016;4(7):549-556.

15. Pavord ID, Korn S, Howarth P, et al. Mepolizumab for severe eosinophilic asthma (DREAM): a multicentre, double-blind, placebocontrolled trial. Lancet. 2012;380(9842):651-659.
16. Bafadhel M, Pavord ID, Russell REK. Eosinophils in COPD: just another biomarker? Lancet Respir Med. 2017;5(9):747-759.

17. Hospers JJ, Schouten JP, Weiss ST, Rijcken B, Postma DS. Asthma attacks with eosinophilia predict mortality from chronic obstructive pulmonary disease in a general population sample. Am J Respir Crit Care Med. 1999;160(6):1869-1874.

18. Pavord ID, Lettis S, Locantore N, et al. Blood eosinophils and inhaled corticosteroid/long-acting $\beta$-2 agonist efficacy in COPD. Thorax. 2016;71(2):118-125.

19. Siddiqui SH, Guasconi A, Vestbo J, et al. Blood Eosinophils: A Biomarker of Response to Extrafine Beclomethasone/Formoterol in Chronic Obstructive Pulmonary Disease. Am JRespir Crit Care Med. 2015;192(4): 523-525.

20. Pascoe S, Locantore N, Dransfield MT, Barnes NC, Pavord ID. Blood eosinophil counts, exacerbations, and response to the addition of inhaled fluticasone furoate to vilanterol in patients with chronic obstructive pulmonary disease: a secondary analysis of data from two parallel randomised controlled trials. Lancet Respir Med. 2015;3(6): $435-442$.
International Journal of COPD

\section{Publish your work in this journal}

The International Journal of COPD is an international, peer-reviewed journal of therapeutics and pharmacology focusing on concise rapid reporting of clinical studies and reviews in COPD. Special focus is given to the pathophysiological processes underlying the disease, intervention programs, patient focused education, and self management protocols.

\section{Dovepress}

This journal is indexed on PubMed Central, MedLine and CAS. The manuscript management system is completely online and includes a very quick and fair peer-review system, which is all easy to use. Visit http://www.dovepress.com/testimonials.php to read real quotes from published authors.

Submit your manuscript here: http://www.dovepress.com/international-journal-of-chronic-obstructive-pulmonary-disease-journal 